\title{
Antibacterial Activity of Stem Bark Extracts of Oroxylum indicum an Endangered Ethnomedicinal Forest Tree
}

\author{
Samatha Talari ${ }^{1}$, Sampath $\mathrm{A}^{2}$, Sujatha $\mathrm{K}^{2}$ and Rama Swamy Nanna ${ }^{1}$ \\ ${ }^{I}$ Plant Biotechnology Research Group, Department of Biotechnology, \\ ${ }^{2}$ Department of Sericulture Kakatiya University, Warangal-506009 (AP), India.
}

\begin{abstract}
The present work has been under taken to study the antibacterial activity of stem bark extracts of $O$. indicum against disease causing gram negative and gram positive bacteria. Antimicrobial activity of solvent extracts of stem bark of Oroxylum indicum has been studied to find out its activity against four important bacterial strains Bacillus subtilis, B. cereus, Staphylococcus albus and S. aureus. The antimicrobial activity of the stem bark extracts was done through well diffusion method and by measuring the inhibition zone around the disc. The results revealed that the aqueous extracts of $O$. indicum exhibited antimicrobial activity against all the microbes under study. The results provided evidence that the species $O$. indicum can be used as a potential source of antimicrobial agent.
\end{abstract}

Keywords: Antimicrobial activity, Oroxylum indicum, Stem bark extract, Zone of inhibition

\section{Introduction}

Traditional medicine is widely spread globally and it is the almost exclusive source of primary health care for $80 \%$ of the world's population [1]. Herbal medicines are regarded by the public and some health care providers to be gentle and safe, despite a paucity of scientific evidence to support such beliefs. The active ingredients of plant extracts are chemicals that are similar to those in purified medications, and they have the same potential to cause serious adverse effects [2]. Medicinal plants and aromatic plants constitute a major source of natural organic compounds widely used in human health care. These plants produce many compounds as secondary metabolites that have no apparent metabolic, physiologic and structural role in the producer, but often have effects on other organisms. In many cases they are believed to function as biochemical defense [3].

The usefulness of any drug depends not only on its therapeutic efficacy but also on its lack of toxicity or adverse side effects. According to published reports, there are several herbal preparations that can produce adverse effects. For example, popular Chinese herbal preparation "jin bu huan" which is used as a pain and insomnia remedy, has been linked with several cases of acute hepatitis. Germanium, a non essential mineral commonly found in many herbal products, has been associated with chronic kidney failure. Kombucha tea, commonly used in the hopes of preventing cancer, relieving arthritis, curing insomnia and stimulating hair regrowth can cause several metabolic disorders [4].

Standardization is an essential measurement for ensuring quality control of herbal drugs [5]. Standardization of herbal products/drugs is more challenging than synthetic drugs. Herbal extracts contain a number of constituents of complex chemical nature and are inconsistent in composition [6]. In most of the cases the biological activity is not exclusively dependent upon the so called active constituents, but is due to synergistic effect of all chemical constituents of the plant. Eventhough biologically inert, many constituents affect the pharmacokinetics and stability of the active constituents [7].

Wound infections are common in developing countries due to poor hygienic conditions. Staphylococcus aureus, Streptococcus pyogenes, Escherichia coli, Pseudomonas aeroginosa, Streptococcus pneumoniae and Klebsiella pneumoniae are some important bacterial strains causing wound infections [8]. A wide range of antibiotics (e.g. erythromycin, tetracyclines, trimethoprim, sulfonamides, gentamycin, etc) are being used at present for treating wound infections [9, 10]. Bacterial resistance to antibiotics is a major therapeutic problem and the rate at which new antibiotics are being produced is slowing [11]. The increasing failure of chemotherapeutics and antibiotic resistance exhibited by pathogenic microbial infectious agents, has led to the screening of several medicinal plants for their potential antibacterial activity. There are several reports in the literature regarding the antibacterial activity of plant extracts $[12,13,14]$.

Plant based pharmaceuticals have been important source for pharmaceutical industries in many parts of the world including India. One among such plant is Oroxylum indicum, belonging to Bignoniaceae. The species $O$. indicum (L) Kurz, is an endangered medicinally important forest tree species. The species of O.indicum, also known as Shyonaka, Sonapatha or Midnight Horror has long been used as an important constituent of several ayurvedic preparations such as Dasamoolarishta and Dasamoolakwaatham [10, 15].

Numerous studies have been investigated on biologically active secondary metabolites such as napthaquinones and iridoids from the stem bark of O.indicum which showed that the stem has more antibacterial effect than the 
root $[16,17,18]$. Isolation of secondary metabolites from the bark of $O$. indicum that it contains antimicrobial, analgesic, antifungal and allergic properties $[19,20]$ and is included in famous ayurvedic formulation Chyawanprash. From ancient times, a vast ethnobotanical lore exists in India which will be very effective in formulation of antimicrobials.

There are very few reports about the bioactive components present in the Oroxylum indicum and also on its antibacterial activity, hence the present study has been undertaken.

\subsection{Plant material}

\section{Materials and Methods}

The stem bark of O.indicum was collected from Mallur Reserve forest flora of Warangal District, Andhra Pradesh, India, and shade dried. Later finely powdered using an electric blender and stored in air tight containers for future use.

\subsection{Preparation of the extracts}

The shade dried powder $(25 \mathrm{gm})$ was used for the extraction with $150 \mathrm{ml} 80 \%$ methanol for 24 hours by using Soxhlet equipment and filtered through $0.45 \mu \mathrm{m}$ membrane filter. This filtrate was evaporated under reduced pressure and dried in a rotator evaporator at $55^{\circ} \mathrm{C}$. Dried extracts were stored in screw cap bottles at $20^{\circ} \mathrm{C}$ and used as stock. Further, the same was diluted by using distilled water to arrive at different concentrations $(1: 1,1: 2 \& 1: 3)$.

The following gram positive and gram negative pathogenic cultures of human and plants were used for testing the antimicrobial activity of plant extracts. These cultures were obtained from different sources listed below and maintained on their respective media.

\subsection{Bacterial cultures / Test organisms}

The following cultures were obtained from Institute of Microbial Technology (IMTECH), Chandigarh and Department of Botany, Kakatiya University, Warangal, Andhra Pradesh, India.

Bacillus cereus KUCC 23

Bacillus subtilis KUCC 17

Staphylococcus aureus MTCC 96

Staphylococcus albus MTCC 96

\subsection{Media used for the assay}

The following different specific growth media were used to culture the microorganisms.

\subsubsection{Nutrient agar (NA)}

$\begin{array}{lc}\text { Peptone } & 5.00 \mathrm{~g} \\ \text { Beef extract } & 3.00 \mathrm{~g} \\ \text { Sodium chloride } & 5.00 \mathrm{~g} \\ \text { Agar } & 20.00 \mathrm{~g} \\ \text { Distilled water } & 1000 \mathrm{ml}\end{array}$

\subsubsection{Nutrient Broth (NB)}

Peptone

Beef extract

Sodium chloride

Distilled water

\section{$5.00 \mathrm{~g}$}

$3.00 \mathrm{~g}$

$5.00 \mathrm{~g}$

$1000 \mathrm{ml}$

\subsubsection{Double strength Nutrient Agar (Ds NA)}

$\begin{array}{lr}\text { Peptone } & 10.00 \mathrm{~g} \\ \text { Beef extract } & 10.00 \mathrm{~g} \\ \text { Sodium chloride } & 5.00 \mathrm{~g} \\ \text { Agar } & 20.00 \mathrm{~g} \\ \text { Distilled water } & 1000 \mathrm{ml}\end{array}$

\subsection{Cultivation techniques}

\subsubsection{Plate preparation}

Using sterile technique, $20 \mathrm{ml}$ aliquots of sterile molten medium were transferred to sterilized petridishes. After solidifying, the plates were used for the assay. 


\subsubsection{Sub-culturing:}

Subcultures were prepared by transferring loopful of inoculum from culture slants to freshly prepared agar slants. These were incubated in the desired conditions, at $37^{\circ} \mathrm{C}$ for $24 \mathrm{hrs}$.

\subsection{Antibacterial activity \\ 2.6.1 Preparation of inoculum}

By the standard method of inoculation [21] an inoculating loop was touched each of four or five well isolated colonies of the same morphological type and inoculum was inoculated into $5 \mathrm{ml}$ of nutrient broth. The broth cultures were allowed to incubate at $37^{\circ} \mathrm{C}$ for $24 \mathrm{hrs}$ until a slight visible turbidity appeared. The turbidity of actively growing broth cultures was then adjusted with broth to obtain a half of MC Farland standard $\left(1 \times 10^{8}\right.$ to 5 $\mathrm{x} 10^{\mathrm{B}} \mathrm{cfu} / \mathrm{ml}$ ). This was used as a starting inoculum for the assay.

\subsubsection{Antimicrobial assay by well diffusion method}

The antimicrobial assay was carried out by the well diffusion or agar cup plate method [22].

\subsubsection{Agar cup plate method}

A standardized 1 to $2 \times 10^{7} \mathrm{cfu} / \mathrm{ml} 0.5 \mathrm{MC}$ Farland standards was introduced onto the surface of sterile agar plate and evenly distributed the inoculum by using a sterile glass spreader. Simultaneously $8 \mathrm{~mm}$ wells were cut from the plate using a sterile cork borer. $50 \mu \mathrm{l}$ of extract at a concentration of $200 \mathrm{mg} / \mathrm{ml}$ was introduced into each well. The agar plates were incubated aerobically at $37^{\circ} \mathrm{C}$. After $24 \mathrm{hrs}$ the inhibition zones were measured with a ruler and compared with the control well containing only DMSO and $10 \mathrm{mg} / \mathrm{ml}$ of Gentamycin as standard.

\section{Results and Discussion}

The stem bark of this plant was tested for antimicrobial activity by agar disc diffusion assay against four important bacterial strains (Bacillus subtilis, B. cereus, Staphylococcus albus, and S. aureus). The antimicrobial activity was studied by measuring the inhibition zone around the disc. Trials were conducted against the bacterial strains for each of the plant extract. The high zone of inhibition at 1:1 concentration is reported. This provides a base for use of the plant in the treatment of bacterial diseases and also helps in discovering a new secondary metabolite, for the industry.

Among the concentrations of stem bark extracts of $O$. indicum as interpreted form the zone size, Bacillus subtilis showed susceptibility towards 1:1 concentration when compared with other proportions. The zone of inhibition was largest $(11.7 \mathrm{~mm})$ at $1: 1$ concentration when compared to other microbial strains under study (Table-1).

The study showed that the extracts investigated were active against bacteria in treated batch in comparison to the control. After incubation, the diameter of clear zone surrounding each disc was measured to the nearest $\mathrm{mm}$. The area of zone was calculated for each replicate assay of disc treated with extract at different concentrations $(1: 1,1: 2 \& 1: 3)$ [23].

At 1:1 concetration, the aqueous extract of $O$. indicum showed greater inhibition of Bacillus subtilis, while more inhibition of Staphylococcus albus was observed at 1:3 concentration against Bacillus cereus; followed by Staphylococcus albus appeared to be more resistant as it showed minimum area of inhibition zone for aqueous extracts of $O$. indicum when compared to the control (Gentamycin). Therefore, these phytochemicals may contribute to its antibacterial activity. This is possibly due to the differences in chemical composition and structure of cell wall of the microorganisms. In conclusion, $O$. indicum extracts exhibited antibacterial activity against both gram (+) ve bacterial strains such as $S$. albus, $S$. aureus, and gram (-) ve bacterial strains such as $B$. subtilis and B. cereus mediating the presence of a broad spectrum of antibacterial compounds in the plant.

In general, bacteria have the genetic ability to acquire resistance against medicinal drugs, hence it is very important to find an alternative treatment [24]. Some of the extracts of the species of Bignoniaceae have shown antimicrobial activity [18]. Among these, species such as Oroxylum indicum, Tabebuai spectabodes, Fernando andenophylla, Steriospermum fibrialum, Dilichandrone spathaceae have been reported, Oroxylum has drawn much attention as it is reported to possess anti-inflammatory, antifungal and antibacterial activities $[15,25]$.

The study showed that activity of different proportions of stem bark extract of $O$. indicum could be an important source of a potent antibacterial medicine. 


\section{Conclusion}

The results showed that this plant could be the source of potent antibacterial medicine, in the treatment of bacterial diseases. In addition the effectiveness of the plant was not due to main active constituents but may be due to the combined action of other chemical compounds such as alkaloids of phenolic nature which are classified as antimicrobial compounds $[26,16]$.

\section{Acknowledgement}

We thank the University Grants Commission, New Delhi, India for providing the financial assistance under Rajiv Gandhi National Fellowship as JRF/SRF (Ref. No. F. 14-2(SC) 2009(SA-III).
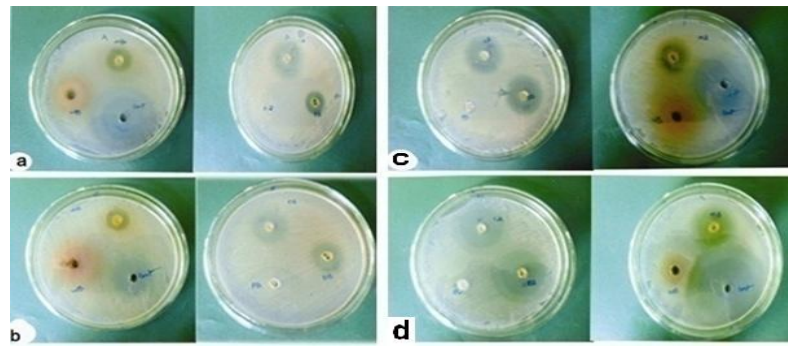

Fig. a-f: Showing the zone of inhibition against aqueous extracts of stem bark $O$. indicum a) Bacillus cereus; b) Staphylococcus aureus; c) Bacillus subtilis; d) Staphylococcus albus

TABLE-1

Effect of stem bark extracts of $O$. indicum on antimicrobial activity on different pathogenic bacteria

\begin{tabular}{|c|c|c|c|c|}
\hline $\begin{array}{c}\text { Concentration of } \\
\text { stem bark extract }\end{array}$ & $\begin{array}{c}\text { Bacillus } \\
\text { subtilis } \\
(\mathbf{Z I} \text { in } \mathbf{~ m m} \pm \\
\mathbf{S E}^{\mathbf{a}} \text { ) }\end{array}$ & $\begin{array}{c}\text { Bacillus } \\
\text { cereus } \mathbf{( Z I} \\
\text { in } \mathbf{~ m m} \pm \\
\mathbf{S E}^{\mathbf{a}} \text { ) }\end{array}$ & $\begin{array}{c}\text { Staphylococcus } \\
\text { albus(ZI in } \mathbf{~ m m} \pm \\
\left.\mathbf{S E}^{\mathbf{a}}\right)\end{array}$ & $\begin{array}{c}\text { Staphylococcus } \\
\text { aureus }(\mathbf{Z I} \text { in } \mathbf{~ m m} \\
\mathbf{\pm} \mathbf{S E}^{\mathbf{a}} \text { ) }\end{array}$ \\
\hline $1: 1$ & $11.7 \pm 0.9$ & $5.2 \pm 1.4$ & $6.6 \pm 0.5$ & $8.7 \pm 0.1$ \\
\hline $1: 2$ & $8.7 \pm 0.4$ & $5.3 \pm 0.4$ & $6.3 \pm 0.3$ & $7.4 \pm 0.3$ \\
\hline $1: 3$ & $7.7 \pm 0.9$ & $4.0 \pm 0.2$ & $5.8 \pm 0.4$ & $8.1 \pm 0.2$ \\
\hline $\begin{array}{c}\text { Control } \\
\text { Gentamycin) }\end{array}$ & $6.3 \pm 0.9$ & $3.0 \pm 0.5$ & $4.0 \pm 0.1$ & $6.2 \pm 0.5$ \\
\hline
\end{tabular}

Data presented as mean of 3 readings; ${ }^{\mathrm{a}}$ Mean \pm Standard Error; ZI $=$ Zone of Inhibition

\section{References}

[1]. Farnsworth Screening plants for new medicines. In: Biodiversity, ed. E.O. Wilson. Publication of National academy press, Washington D.C. USA, 1998, pp.83 - 97.

[2]. De Smet PAGM. Health risks of herbal remedies. An update. Clin Pharmacol Therapeut. 2004; 76: 1 - 17

[3]. Jain R, Nagpal S, Jain S and Jain S.C. Chemical and biochemical evaluation of Bauhinia species. Journal of Medicinal and Aromatic Plant Sciences. 2004; 26(1):48-50.

[4]. Whitney E. \& Rolfes S. Understanding nutrition. Belmont, Ca., USA, West/Wadsworth. Eighth ed. (ed. W. Rolfes) 1999.

[5]. Sanjay J, Sweta S, Rakesh B, Praveen K. Standardization of Dashamula arista: A polyherbal Formulation. Pharmacog J. 2009, 1: $215-200$.

[6]. Jadhav RB, Patil CR, Bhpoe S, Murumkar CV. Herbal drug standardization and quality assurance of raw materials: a rational approach. Nat Prod Rad. 2003; 2:134 - 140.

[7]. Handa SS. 4th International Congress of Ethnopharmacology, precongress workshop on medicinal plants. 1994, Lucknow, India.

[8]. Mertz P, Ovington L. Wound healing microbiology. Dermatol Clin. 1993; 11:739.

[9]. Lullmann H, Mohr K, Ziegler A, Bieger D. Color Atlas of Pharmacology. 2 edn. Publication of Thieme Stuttgart. USA. 2000.

[10]. Anonymous. The Ayurvedic Pharmacopoeia of India.Government of India, Ministry of health and family welfare department of Indian system of medicine and Homeopathy, New Delhi, India, 1998; 209-210.

[11]. Russell AD. Antibiotic and biocide resistance in bacteria: Introduction. J Appl Microbiol (Symp Suppl). 2002; 92: 1S - 3S .

[12]. Lingadahalli PS, Vagdevi HM, Basavanakote MB, Vaidya V. Evaluation of antimicrobial and analgesic activities of Aporasa lindleyana (euphobiaceae) bark extract, Int J Green Pharm, 2008; 2: 155 - 157.

[13]. Latha C, Shriram VD, Jahagirdar SS, Dhakephalkar PK, Rojatkar SR. Antiplasmid activity of 1' - acetoxychavicol acetate from Alpinia galanga against multi - drug resistant bacteria. J Ethnopharmacol. 2009; 123: 522 - 525 .

[14]. Pavithra PS, Sreevidya N, Verma RS. Antibacterial activity and chemical composition of essential oil of Pamburus missionis. J Ethnopharmacol. 2009; 124: $151-153$.

[15]. Warrier PK, Nambiar VPK, Ramankutty C. Oroxylum indicum. In compendium of 500 species Indian Medicinal plants. Vol. IV Madras, Orient Longman Ltd., 1995; 186-190.

[16]. Radhika LG, Meena CV, Sujha Peter, Rajesh K.S. Phytochemical and antimicrobial study of Oroxylum indicum. Ancient Science of Life, 2011; 30(4): 114-120.

[17]. Kingston DG and Rao V. Plant anticancer agents. XII. Isolation and structure elucidation of new cytotoxic quinones from Tabebuia cassinoides. J. Nat.Prod, 1982. 
[18]. Akunyili DN, Houghton PJ and Raman AR. Antimicrobial activities of the stem bark of Kigelia pinnata, J.Ethnopharmacol. 1991;35: 173- 177 .

[19]. Rasadah MA, Houghtom PJ, Amala R, Hoult JRS. Antimicrobial and anti-inflammatory activity of extracts and constitutes of Oroxylum indicum vent. Phytomedica.1998; 5: 375-378.

[20]. Vasanth S, Natarajan M, Sundaresan R, Rao RB, Kuundu AB. Ellagic acid Oroxylum indicum vent, Indian drugs. 1991; 28 (11):507.

[21]. Bauer. The complete Idiot's guide to total nutrition. Alpha books, 2002; 76-78.

[22]. Desta B., Ethiopian traditional herbal drugs part II. Antimicrobial activity of 63 medicinal plants, J. Ethnopharmacol. 2005; 100: 168-175.

[23]. Jerkins KM, Jensen PR and Fenical W. Bioassay with marine organisms: Part II. Marine microbial chemical ecology. In: Methods in chemical ecology. Haynes K, Millar JC (eds), Chapman and Hall, New York, 1998; 1-32.

[24]. Joao PC, Tome J, Neves M, Tome AC, Cavaleiro JAS, Soncin M, Magaraggia M, Ferro S and Jori G. Synthesis and Antibacterial Activity of New Poly-S- lysine-Porphyrin Conjugates. J. Med. Chem. 2004; 47: 6649- 6652.

[25]. Jayaram K and Prasad MNV. Genetic diversity in Oroxylum indicum (L.) Vent. (Bignoniaceae), a vulnerable medicinal plant by random amplified polymorphic DNA marker. Afr. J. Biotech. 2008, 7 (3): 254-262.

[26]. Rojas, D, Hermandez, L, Pereda-Mirands R, Meta R. Screening for antimicrobial activity of crude drug extracts and pure natural products from Mexican medicinal plants. J. Ethnopharmacology. 1992; 35:275-283. 